\title{
A potential recovery of a population of the sand lizard Liolaemus lutzae Mertens, 1938 in an area within its range: a lizard endemic and threatened with extinction
}

\author{
Rocha, CFD. ${ }^{\text {a* }}$, Siqueira, $C C{ }^{\mathrm{a}, \mathrm{b}}$ and Ariani, $C V^{\mathrm{a}}$ \\ aDepartamento de Ecologia, Universidade do Estado do Rio de Janeiro - UERJ, \\ Rua São Francisco Xavier 524, CEP 20550-019, Rio de Janeiro, RJ, Brazil \\ 'Programa de Pós-Graduação em Ecologia, Universidade Federal do Rio de Janeiro - UFRJ, \\ *e-mail: cfdrocha@uerj.br \\ Received September 21, 2007 - Accepted March 24, 2008 - Distributed February 28, 2009
}

\begin{abstract}
The endemic and threatened lizard Liolaemus lutzae has a relatively small geographic range restricted to only $200 \mathrm{~km}$ of along the coast of Rio de Janeiro State, Brazil, which are habitats under intensive anthropic disturbance. At the Barra da Tijuca beach, in Rio de Janeiro city an estimate of the population abundance made in 1991, compared to a previous estimate made in 1984, showed a considerable decrease (about 65\%). Most of the decrease was attributed to anthropic disturbances that locally affected the beach vegetation, the species habitat. In this study we present estimates made in 2002 and in 2006 at the same area and compare them with the estimates of 1984 and 1991, using the same methodology in order to make comparable the data from different samplings years and to evaluate the present status of the local population. The estimated indexes of L. lutzae abundance in 2002 and in 2006 were higher than that of 1991. There was a significant increase in the mean number of recorded lizards in 2002 compared to 1991, but the mean number of lizards sighted in 2006 remained stable when compared with that of 2002. Our data based on the index of abundance recorded suggested that the number of L. lutzae at Barra da Tijuca beach recorded increased, which can be indicative of a potential recovery of the local population.
\end{abstract}

Keywords: Liolaemus lutzae, endemic lizard species, population recovery, restinga, threatened species.

\section{Uma possível recuperação de uma população do lagarto de areia Liolaemus lutzae em uma área de sua ocorrência: um lagarto endêmico e ameaçado de extinção}

\begin{abstract}
O lagarto endêmico e ameaçado de extinção Liolaemus lutzae possui distribuição geográfica relativamente reduzida a apenas $200 \mathrm{~km}$ ao longo da costa do Estado do Rio de Janeiro, Brasil, hábitats sobre intensa pressão de degradação. Na praia da Barra da Tijuca, cidade do Rio de Janeiro, uma estimativa do tamanho populacional feita em 1991 foi comparada a uma estimativa anterior feita em 1984, mostrou considerável decréscimo populacional (aproximadamente $65 \%$ ). Grande parte deste decréscimo foi atribuída a distúrbios antrópicos que afetaram localmente a vegetação de praia, o hábitat da espécie. Neste estudo, apresentamos estimativas feitas em 2002 e 2006 na mesma área e as comparamos com as estimativas de 1984 e 1991 Utilizamos a mesma metodologia, de modo a avaliar o presente status da população local. Os índices estimados da densidade populacional em 2002 e 2006 foram maiores que em 1991. Houve aumento significativo no número médio de lagartos amostrados em 2002 em comparação a 1991, porém o número médio de lagartos observados em 2006 permaneceu estável quando comparado às amostragens de 2002. Nossos dados sugerem que, após 2002, houve um aumento no número de L. lutzae registrados na praia da Barra da Tijuca com uma potencial recuperação da população local.
\end{abstract}

Palavras-chave: Liolaemus lutzae, espécies endêmicas, recuperação de população, restinga, espécie ameaçada.

\section{Introduction}

The lizard Liolaemus lutzae (Mertens, 1938) (Liolaemidae) is an endemic and threatened species and has a relative small range restricted to beaches of sand dune habitats (called "restingas") of Rio de Janeiro state in Brazil (only $200 \mathrm{~km}$ extent of range). These areas are under intensive anthropic disturbance (Rocha et al., 2003 ; 2007) and, as a result, some populations have dramatically declined in different localities along its range (e.g. Rocha and Bergallo, 1992; but see Rocha et al., 2003). This species is currently included in the Checklist 
of Brazilian Threatened Fauna as critically endangered (IBAMA, 2003; Martins, 2005; Rocha et al., 2008).

At the Reserva Ecológica de Marapendi, a Conservation Unit in Rio de Janeiro state, Brazil, a study estimating population status of $L$. lutzae indicated that there was a considerable decline from 1984 to 1991 (Rocha and Bergallo, 1992). The estimated population loss was about $65 \%$ and was attributed to the wide range of anthropic disturbances on the beach habitat, which lead to the loss of vegetation (Rocha and Bergallo, 1992). The main disturbances the authors reported at that time were: the alteration of the beach habitat due to road construction, the traffic of vehicles on the remaining beach vegetation, and the removal of vegetation for the establishment of commercial trailers and volleyball sand-courts (Rocha and Bergallo, 1992). These problems remained until 2000 when the Secretaria de Meio Ambiente (Environmental Bureau) of the municipality of Rio de Janeiro started in 2001 a program for environmental recovery of the area. Among the actions carried out were the removal of the of commercial trailers and volleyball sand-courts installed on the vegetation, the building of a fence to prevent the entrance of vehicles onto the beach habitat and the establishment of specific passages for access to the beach in order to reduce the trampling on vegetation and the recovery of the beach area vegetation by planting seedlings and adults of different plant species.

Considering the significant improvement in the recovery of the beach vegetation at the Reserva Ecológica de Marapendi that followed such a program, it is important to know the present status of the local population of $L$. lutzae. Thus, in this study we present estimates of an index of the population abundance of $L$. lutzae at the Reserva Ecológica de Marapendi, Rio de Janeiro State, in 2002 and in 2006 and compare with the estimates of 1984 and 1991 presented by Rocha and Bergallo (1992).

\section{Methodology}

This work was carried out in 2002 and 2006, at the beach $\left(23^{\circ} 00^{\prime} 92.7^{\prime \prime} \mathrm{S}\right.$ and $\left.43^{\circ} 24^{\prime} 81.9^{\prime \prime} \mathrm{W}\right)$ of the restinga of the Reserva Ecológica de Marapendi, a Conservation Unit, located within Rio de Janeiro city, in Rio de Janeiro state, southeastern Brazil. Restingas are quaternary coastal ridges with sandy substrate covered with herbaceous and shrubby vegetation.

A total of six 30-minute transects were done in 2002 and another six in 2006 (totaling 180 minutes per year). Transects were done using the same criteria as those previously done in 1984 and 1991, and at the same sampling site, with the same hourly interval (from 08:30 to 10:00 AM, which corresponds to the peak of activity of L. lutzae; Rocha, 1988; 1995), and under the same weather conditions (i.e. sunny days), to preserve conditions similar to those under which the previous former estimates were done (Rocha and Bergallo, 1992). To make comparable the data from the different studies and samplings years, we carefully followed the same methodology used in those previous studies which could in turn better allow the present status of the local population. Also, because marking lizards was not operational (due to difficulties of capturing such lizard species in a habitat where they escape easily and rapidly to their holes), we opted to perform all transects toward the same direction to avoid the recounting of individual lizards and in this case making each observation independent. This method proved to efficiently estimate the number of effective lizards seen along a particular area. During each transect, observers walked at a moderate pace along the beach habitat (see Rocha, 1996). We estimated a standardized index of L. lutzae relative abundance for each year of sampling by dividing the total number of lizards sighted at that particular year by the total time (in minutes) spent in transects in that year. This estimated index of abundance was expressed as individual $/ \mathrm{min} / \mathrm{man}$. To verify if there was an increase of the population abundance after the recovery of the area, we compared the mean number of lizards recorded in transects between 1991 and 2002 using a Two-Sample $t$-test (Zar, 1999). This same test was also used to verify if there was a stabilization of the mean number of lizards following the environmental recovery program (comparing the samples of 2002 and 2006). Basic statistics are presented as arithmetic mean \pm standard deviation.

\section{Results and Discussion}

The abundance estimates of $L$. lutzae recorded in 2002 and 2006 at the Reserva Ecológica de Marapendi were, respectively, 0.5 and $0.4 \mathrm{ind} / \mathrm{min} / \mathrm{man}$ (Table 1). These abundance values were higher than those of 1991 $(0.1 \mathrm{ind} / \mathrm{min} / \mathrm{man})$ when the population stock decreased due to habitat degradation, and close to the value of 1984 ( $0.3 \mathrm{ind} / \mathrm{min} / \mathrm{man})$, when the population was not yet influenced by those reported factors causing the destruction of the beach habitat (Rocha and Bergallo, 1992).

There was a significant increase $(\mathrm{t}=-4.27, \mathrm{df}=8$, $\mathrm{p}<0.05)$ in the mean number of recorded lizards in 2002 $(15.2 \pm 3.1)$ when compared to $1991(7.5 \pm 2.1)$ (Rocha and Bergallo, 1992). However, the mean number of lizards sighted in transects in $2006(12.5 \pm 6.5)$ did not differ significantly $(\mathrm{t}=0.90, \mathrm{df}=10, \mathrm{p}=0.39)$ from the value of 2002 (Table 1) suggesting that the population has stabilized. Our data are suggestive that the increase in population abundance detected in 2002 probably resulted from the recovery of the beach habitat, because some portions that were previously negatively affected by different sources of disturbance are now completely covered by the beach vegetation.

The recovery of the vegetation of the beach habitat is important for $L$. lutzae because the plants of these areas are also an important food source to these lizards (Rocha, 1991), especially the leaves and flowers of four species (Blutaparon portulacoides, Alternanthera maritima, 
Table 1. Time spent in transects (TT), Index of estimated relative abundance (A) and mean number of lizards ( \pm standard deviation) for the population of the sand lizard Liolaemus lutzae at Restinga da Reserva Biológica de Marapendi, in Barra da Tijuca beach, Rio de Janeiro State, Brazil in different years of sampling. Data from 1984 and 1991 are provided by Rocha and Bergallo (1992).

\begin{tabular}{cccc}
\hline Year & TT $(\mathbf{m i n})$ & A (ind/min/man) & Number of lizards \\
\hline 1984 & 243 & 0.3 & $21.2 \pm 3.3$ \\
1991 & 237 & 0.1 & $7.5 \pm 2.1$ \\
2002 & 180 & 0.5 & $15.2 \pm 3.1$ \\
2006 & 180 & 0.4 & $12.5 \pm 6.5$ \\
\hline
\end{tabular}

Ipomoea pes-caprae and I. litoralis; Rocha, 2000). Other plants, such as the sand palm Allagoptera arenaria and the cactus Cereus fernambucencis, are sources of shelter and thermoregulation sites (Rocha, 1988; 1991). Moreover, a number of arthropods that constitute part of the diet of L. lutzae (Rocha, 1989) live among the beach vegetation (Rocha, 1996).

Considering that the beach habitat is the specific environment of L. lutzae, it is important to preserve the vegetation to permit the maintenance of the local populations. Our data have shown that the recovery of the beach habitat at the Reserva Ecológica de Marapendi may be a good example that an increase of the abundance of L. lutzae along its range could be attained if the beach habitats along its range are recomposed. Thus, this study is a good example of how the recovery of habitat quality potentially can affect positively populations of $L$. lutzae and may help to create constructive strategies to prevent local extinctions of the species along the beaches of Rio de Janeiro state.

Acknowledgements - This study was supported over time by grants of the Edital Espécies Ameaçadas of the Fundação Biodiversitas/CEPAN (process No. 078H/022004) and ICMBio of Instituto Chico Mendes, from the Conselho Nacional do Desenvolvimento Científico e Tecnológico (CNPq) (processes No. 477715/2006-0 and 307653/03-0 to CFDR) and from FAPERJ (through Programa Cientistas do Nosso Estado, Process E-26/100.471.2007). During this study CCS received a Graduate fellowship from Fundação de Amparo à Pesquisa do Estado do Rio de Janeiro - FAPERJ. The Instituto Biomas provided some logistic support to this study. Davor Vrcibradic kindly revised the text.

\section{References}

INSTITUTO BRASILEIRO DO MEIO AMBIENTE E DOS RECURSOS NATURAIS RENOVÁVEIS - IBAMA, 2003. Lista oficial da fauna brasileira ameaçada de extinção. Brasília: Ministério do Meio Ambiente (MMA).

MARTINS, M., 2005. Répteis. In: MACHADO, ABM., MARTINS, CS. and DRUMMONT, GM. (Orgs.). Lista da Fauna Brasileira Ameaçada de Extinção. Belo Horizonte: Fundação Biodiversitas, p. 55-58.

MERTENS, R., 1938. Bemerkungen uber die Brasilianischen Arten der Gattung. Liolaemus. Zoologischer Anzeiger, vol. 123, no. 719 , p. $220-222$.
ROCHA, CFD., 1988. Ritmo de atividade e microclimatologia do habitat de Liolaemus lutzae (Sauria: Iguanidae) na Restinga de Barra de Maricá, RJ. In Anais do VI Seminário Regional de Ecologia e Anais do Seminário Regional de Ecologia de São Carlos, 22 a 24 de outubro de 1988. São Carlos: Departamento de Ciências Biológicas, Universidade Federal e São Carlos, 1988. p. 269-281.

-, 1989. Diet of a tropical lizard (Liolaemus lutzae) of southeastern Brazil. Journal of Herpetology, vol. 23, no. 3, p. 292-294.

-, 1991. Composição do habitat e uso do espaço por Liolaemus lutzae (Sauria: Iguanidae) em uma área de Restinga. Revista Brasileira de Biologia = Brazilian Journal of Biology, vol. 51, no. 4 , p. 839-845.

-, 1995. Ecologia termal de Liolaemus lutzae (Sauria: Tropiduridae) em uma área de Restinga do Sudeste do Brasil. Revista Brasileira de Biologia = Brazilian Journal of Biology, vol. 55 , no. 3, p. 481-489.

-, 1996. Seasonal shift in lizard diet: the seasonality In food resources affecting the diet of Liolaemus lutzae (Tropiduridae). Ciência e Cultura, vol. 48, no. 4, p. 264-270.

-, 1996. Indirect estimate of a lizard population size and age structure. Vida Silvestre Neotropical, vol. 5, no. 2, p. 143-146.

-, 2000. Selectivity in plant food consumption in the lizard Liolaemus lutzae from Southeastern Brazil. Studies on Neotropical Fauna and Environment., vol. 35, no. 1, p. 14-18.

ROCHA, CFD. and BERGALLO, HG., 1992. Population decrease: the case of Liolaemus lutzae, an endemic lizard of southeastern Brazil. Ciência e Cultura, vol. 44, no. 1, p. 52-54.

-, 1997. Intercommunity variation in the distribution of abundance of dominant lizard species in restinga habitats. Ciência e Cultura, vol. 49 , no. 4 , p. $269-274$.

ROCHA, CFD., BERGALLO, HG., VAN SLUYS, M. and ALVES, MAS., 2003. A biodiversidade nos grandes remanescentes florestais do Estado do Rio de Janeiro e nas restingas da Mata Atlântica. São Paulo: Editora Rima, 160 p.

ROCHA, CFD., SIQUEIRA, CC. and ARIANI, CV., 2008. Liolaemus lutzae Mertens 1938. in MACHADO, ABM., DRUMMONT, GM. \& PAGLIA, A.P. (Eds.), Livro Vermelho da Fauna Brasileira Ameaçada de Extinção, Volume II. Brasília: Ministério do Meio Ambiente (MMA), p. 345-347.

ROCHA CFD., BERGALLO, HG., VAN SLUYS, M., ALVES, MAS. and JAMEL, CE., 2007. The remnants of restinga habitats in the Brazilian Atlantic Forest of Rio de Janeiro State, Brazil: Habitat loss and risk of disappearance. Brazilian Journal of Biology, vol. 67, no. 2, p. 263-273.

ZAR, JH., 1999. Biostatistical analysis. Upper Saddle River: Prentice-Hall, 663 p. 